\title{
Transdisciplinarni pristup u razmatranju odnosa znanost - teologija
}

\author{
Krešimir Cerovac*
}

\begin{abstract}
Sažetak
Nužnost dijaloga između teologije, religije i prirodnih znanosti stavlja pred nas zahtjev za promišljanjem najučinkovitijega pristupa složenim pitanjima i problemima teologije, religije i prirodnih znanosti. Transdisciplinarnost se pokazuje kao izvrsno rješenje, osobito za probleme koji ne mogu biti riješeni jednostrano. Naime, povezujući promišljanja o materijalnom svijetu ili religiji koja polaze s različitih motrišta, transdisciplinarni pristup pokazuje se kao posrednik koji u prvi plan stavlja ono što ljudska bića povezuje na razini univerzalno ljudskoga. Riječ je o „kritičkoj racionalnosti”, tj. novom načinu razmišljanja, suprotnom redukcionističkomu racionalizmu, koji naglašava objektivnost, a temelji se na kontroliranom sukobu uzrokovanom paradoksima. Transdisciplinarnost tako stvara novu kvalitetu, koja nije aritmetički zbroj pojedinih disciplina i omogućuje artikuliranje, odnosno svezu između dvaju, na prvi pogled, suprotstavljenih disciplinarnih razmišljanja.

Ključne riječi: dijalog, dijaloška majeutika, epistemološke granice, interdisciplinarnost, multidisciplinarnost, religija, scijentizam, teologija, transdisciplinarni aksiomi, transdisciplinarnost, znanost
\end{abstract}

\section{Uvod}

Dijalog između znanosti i teologije o zbilji čovjeka iznimno je važan, jer omogućuje čovjeku da ponovno pronađe svoje jedinstvo stekavši jasnu svijest o svojoj dvostrukoj dimenziji, i to horizontalnoj (kultura, traganje, tehnologija i dr.) i vertikalnoj (smisao postojanja i djelovanja). Razumijevanjem toga jedinstva produbljuje se otajstvo Utjelovljenja, u kojem se je Bog učinio čovjekom u Isusu Kristu. Govor o Bogu kao Stvoritelju ostaje prazan ako nije u povezanosti sa znanstvenim opisom prirode. Zbog svoje misije naviještanja, Crkva mora preko teologije uvijek težiti za produbljivanjem vjerskih sadržaja, koristeći se postignućima filozofske i znanstvene misli određenoga doba. Teologija mora uvijek biti

* Mr. sc. Krešimir Cerovac, dipl. ing. el. techn. Adresa: Našička 2, 10000 Zagreb, Hrvatska, Eadresa: kresimir.cerovac@xnet.hr 
u dodiru sa suvremenom kulturom, ako želi provoditi svoju dužnost. A to znači, kako kaže papa Ivan Pavao II., Božju objavu posredovati ljudima određenoga vremena i određenoga mjesta:

Teologija se ne može indiferentno odnositi prema novim filozofskim ili znanstvenim teorijama. Budući da ta saznanja postaju dio intelektualne kulture vremena, teolozi ih moraju razumjeti i testirati njihovu vrijednost u iznošenju iz kršćanske vjere na vidjelo neke mogućnosti koje još nisu ostvarene (Ivan Pavao II., 1988). ${ }^{1}$

»Kao i u prijašnja vremena, a možda još i više, teolozi i učeni ljudi u Crkvi pozvani su danas da sjedine vjeru sa znanošću i mudrošću da tako pridonesu njihovom prožimanju. Ta je zadaća danas to veća zbog napretka ljudske znanosti, njezine metodologije kao i dostignuća u poznavanju svijeta i čovjeka« (RH 19).

A i papa Franjo u apostolskoj pobudnici Evangelii gaudium slično govori: »Crkva, u svojoj evangelizacijskoj zadaći, cijeni i potiče karizmu teologa i napor koji ulažu u teološko istraživanje koje promiče dijalog sa svijetom kulture i znanosti« (EG 133). Konačno: u enciklici Fides et ratio papa Ivan Pavao II. izražava vjeru »da se vjera i znanost uzajamno pomažu, dok jedna za drugu istodobno imaju funkciju kritičke i pročišćavajuće prosudbe, te su ujedno međusobni poticaj za daljnje istraživanje i produbljivanje (FR 100).

Pritom treba naglasiti da uvažavanje znanosti ne znači ustupak u vjerskom pogledu. Vodeći računa o dostignućima prirodnih znanosti, ne relativizira se dogmatski sadržaj vjere, nego mu se daje njegov prirodni ili ljudski temelj. Sve to zahtijeva trećega posrednika da bi se stvorile nove integrativne veze, koje ne postoje unutar obiju disciplina. To može biti transdisciplinarni pristup.

\section{Znanost kao ideologija}

Modernu se znanost danas često prikazuje kao alternativu religiji, odnosno kršćanstvu. Za spoznaju istine dovoljna je, tvrdi se, prirodna znanost, odnosno istina, općenito gledajući, nije više podudaranje s vječnim Logosom ni podudaranje razuma i stvarnosti ${ }^{2}$ kao od Boga stvorene, nego je istina tek podudaranje sudova unutar nekoga sustava poput znanosti. Činjenica je da vodeći položaj prirodnih znanosti u suvremenom svijetu ima golem utjecaj na suvremeni zdravi razum i to teologija ne smije podcijeniti. Znanost pruža dojam da ljudi žive u svijetu činjenica i da znanost može pronaći najučinkovitija rješenja za suvremeni život. Čovjek je stvorio jedan novi, umjetni svijet tehnizirane, ili neprirodne, prirode, u kojoj je funkcionalna svrsishodnost dovela do stanja ugroženosti baš čovjeka, odnosno ugroženosti dostojanstva njegove osobnosti. Werner Heisenberg kaže: »Svrsishodnost može voditi u kaos, ako i same svrhe nisu shvaćene kao dijelovi [...] nekog višeg reda. Svrsishodnost je smrt čovječnosti!« (Kusić, 1997, 444). Te svrhe treba shvatiti, kaže Heisenberg, kao »dijelove jedne veće sveze«,

1 Citate koji su izvorno na stranim jezicima na hrvatski je preveo autor rada.

2 Zbirni pojam za cjelinu pojedinačnih materijalnih predmeta. 
koja je nekad označavana »kao Božji poredak«. Kao zaključak može se reći da je današnja kultura obilježena znanošću kao modelom suvremenoga znanja. Tu činjenicu uviđa primjerice Drugi vatikanski koncil:

Današnji nemir i promjene životnih prilika povezane su s dubljim preobražajem, tako da u obrazovanju sve veću važnost zadobivaju matematičke i prirodoslovne i antropološke znanosti, a na praktičnom području tehnika, koja iz tih znanosti proistječe. Taj mentalitet pozitivnih znanosti oblikuje kulturu i način mišljenja drugačije nego u prošlosti (GS 5).

Nije nikakvo čudo da se je u današnjoj civilizaciji nametnulo pitanje o znanosti kao ideologiji iako s političkoga stajališta vlada uvjerenje da se živi u vremenu »nakon sumraka ideologija «, »kraja velikih pripovijesti« i »smrti utopija « (Mościcki, 2015, 5; Matulić, 2006, 317). Dakako, ako se pod pojmom ideologije podrazumijevaju dogmatizam, nesnošljivost, lažna svijest i neupitnost, onda znanost ne može biti shvaćena kao ideologija. Štoviše, znanost je u tom pogledu antidogmatska, jer uvažava drukčije mišljenje te ostavlja prostor za provjeru i opovrgavanje svojih hipoteza i teorija (Matulić, 2006, 318). No, problem znanosti kao ideologije nastaje kad se tvrdi da znanost kao takva nema granica, te da može ponuditi rješenje svakoga problema, pa tako i onoga konačnoga o podrijetlu, smislu i svrsi svijeta i čovjeka. Tvrdnja da znanstvena spoznaja nema granica odvodi u scijentizam (znanstveni materijalizam) ili u način koji apsolutizira znanstvenu spoznaju. Materijalisti vjeruju da će svi fenomeni konačno biti objašnjeni u smislu djelovanja materijalnih komponenti, koje su jedini učinkoviti uzroci u svijetu.

Logički pozitivizam u razdoblju od dvadesetih do četrdesetih godina 20. stoljeća tvrdio je da znanstveni govor (diskurs) osigurava sva pravila za jedan svesmislen jezik. Tvrdilo se je da su empiričke pretpostavke jedini smisleni iskazi provjerljivi osjetilnim podatcima. Za etičke, metafizičke i religijske iskaze smatrano je da nisu ni istiniti ni neistiniti, nego pseudoiskazi bez značenja, izrazi emocija ili pretpostavke lišene spoznajnih važnosti. Cijela su područja ljudskoga jezika $\mathrm{i}$ iskustva bila time eliminirana iz ozbiljnih rasprava, jer nisu bila podložna znanstvenomu potvrđivanju, koje je, kako je uporno dokazivano, osiguravala samo znanost. Fizičar i katolički svećenik ukazao je na to da je znanstveno razmišljanje u 20. stoljeću dovelo do oblikovanja i razvoja nove epistemologije, u kojoj razumni subjekt ima središnju ulogu. U spoznajnom procesu čovjek postaje integrirajući i integrativni dio (Pop i Vereş, 2009, 359).

U knjizi Slučaj i nužnost Jacques Monod daje pregledno izvješće o molekularnoj biologiji protkano obranom znanstvenoga materijalizma i tvrdi da je biologija dokazala da u prirodi ne postoji svrha. »Čovjek najzad zna da je sam u bezosjećajnoj svemirskoj neizmjernosti iz koje se je pojavio slučajem. Samo je slučaj izvor svih novosti, svih stvorenja u biosferi« (Monod, 1971, 180). Slučaj je slijep i apsolutan, jer su slučajne mutacije nepovezane s potrebom organizma. Uzroci pojedinih varijacija potpuno su nezavisni od okolišnih sila prirodne selekcije. Monod je zauzeo nepomirljiv redukcionistički pristup: »Sve može biti svedeno na jednostavna, očigledna mehanička međudjelovanja. Stanica je stroj« (Monod, 1971, 111). »Životinja je stroj. Čovjek je stroj« (Monod, 1971, 45). 
Ilustrativan je i primjer eksplicitne obrane znanstvenoga materijalizma Edwarda O. Wilsona. Njegovo pisanje ulazi u trag genetskoga i evolucionističkoga podrijetla socijalnoga ponašanja insekata, životinja i ljudi. Postavio je pitanje kako se je moglo pojaviti, i ustrajati, samožrtvujuće ponašanje kod insekata, primjerice kod mrava, ako je time ugrožena njihova reproduktivna sposobnost. Wilson pokazuje da takvo altruističko ponašanje povećava preživljavanje bliskih srodnika sa sličnim genima (primjerice u koloniji mrava). Selektivni pritisci potiču takvo samožrtvovanje. Vjeruje da se ljudsko ponašanje može svesti na biološko podrijetlo i postojeću genetsku strukturu. »Nije nerealno kazati da su sociologija i ostale sociološke znanosti, kao i društvene znanosti, krajnje grane biologije koje treba uključiti u Modernu Sintezu « (Willson, 1975, 4). Svijest je objasnio kao »epifenomen živčane mašinerije mozga« (Wilson, 1988, 195). Wilson smatra da su religijski postupci bili koristan mehanizam u ranoj povijesti čovječanstva, jer su tada doprinijeli koheziji skupine. No, moć religije nestala je za sva vremena kada je sve u potpunosti objašnjeno evolucijom: tada je religija zamijenjena filozofijom znanstvenoga materijalizma.

Vidljivo je da su zapravo pojedini znanstveni koncepti protegnuti i ekstrapolirani izvan područja njihove znanstvene uporabe, odnosno da su "napuhani" u jednu navodno sveobuhvatnu prirodnu filozofiju. Znanstveni koncepti i teorije iskorištene su, neopravdano, za iscrpno opisivanje stvarnosti, a pritom je zanemaren apstraktni i selektivni karakter znanosti. Filozof Alfred North Whitehead to naziva »zabludom o zagubljenoj konkretnosti« (pogrješka zamjenjivanja apstraktnoga konkretnim) (Whitehead, 1997, 52). To se može opisati i kao oblikovanje metafizike izvan metode: »Nijekanje metafizike i podržavanje materijalizma samo po sebi je kretanje u metafizici. Tvrdnja da znanost može objasniti sve nikad ne može doći iz znanosti. Uvijek je to samo izjava o znanosti« (Trigg, 2015, 54). No, budući da znanstveni materijalizam polazi od znanstvenih ideja, ima bitan utjecaj u današnjem vremenu, koje posebice respektira znanost. A na to dodatno utječe i uvjerenje koje zastupaju neki znanstvenici da postoji tzv. teorija o svemu, koja bi trebala osigurati konačan odgovor na sva vječna religijska pitanja, pokazujući tako da nema prostora ostavljenoga za stvarnost izvan prirodnoga svijeta.

\section{Spoznajne granice znanosti}

Znanost nikad ne prestaje postavljati nova i zanimljiva pitanja o svemiru i ljudima. Budući da ih sama ne može riješiti, mora se osloniti na filozofiju, etiku, religiju i teologiju. Svi ti aspekti temelj su za dijalog između vjere i znanstvene kulture. Činjenica je da spoznajne granice znanosti postoje, pa se u slučaju nijekanja te činjenice može govoriti o ideologizaciji znanosti, u smislu ideološke zloporabe znanosti, tj. korištenja znanosti i znanstvene spoznaje u svrhe koje nemaju ni epistemološki ni metodološki status znanstvenosti (Matulić, 2006, 317). Ideologizacija znanosti dakle događa se kad se previdi činjenica da znanost ostaje i nadalje jedan nesavršeni i nedovršeni totalitet znanja. Još uvijek važi izreka Emila 
De Bois Reymonda: Ignoramus et ignorabimus (»ne znamo, a nećemo ni znati «), kojom taj fizičar označava granice naše spoznaje prirode. ${ }^{3}$ Time je Reymond jasno ukazao, doduše s agnostički motiviranoga polazišta, na postojanje granica i jednostranosti prirodoslovnih istraživanja. Čovjek je nesiguran posvuda gdje ga napušta egzaktna znanost, a tek po mjeri svojega pouzdanja on opaža kako je, usprkos svemu, malen djelić stvarnosti, u kojoj mu ta znanost pruža sigurnost (Benedikt XVI., 2008, 21). Ne znamo i nećemo nikad znati podrijetlo materije, odnosno materijalnoga kozmosa, nećemo znati podrijetlo života na zemlji, zatim pojavu svijesti, podrijetlo i bit osjetilne spoznaje, podrijetlo samosvijesti i razuma. Ne znamo i nećemo znati odgovore na bitna pitanja koja pogađaju ljudsku egzistenciju. »Ponekad mislimo da nešto znamo, kad vidimo u zoru visoke vrhove, ili kad čujemo određene akorde ili melodije. No, čak ni tada ne znamo. Ne smijemo djelovati kao da smo znali ovo ili ono, čak i u elementarnom načinu, kad samo nagađamo« (Barth, 2003, 46).

U suvremenom dobu, u kojem se evidentira enormna fragmentacija znanosti na nebrojeno mnoštvo znanstvenih područja i disciplina, teško se je oteti dojmu da znanost ubrzano korača prema ostvarenju totalnoga horizonta znanja i spoznaje. U mnoštvu znanosti koje ju opredmećuju, priroda je razjedinjena: subatomska razina, makromehanička razina, razine kemijskih, biologijskih i psihologijskih procesa. Stvarnost, kako ju vide prirodne znanosti, sve se više raspada na pojednostavljene postavke. Stvarnost čovjeka sve se manje promatra kroz optiku cjeline, a sve više kroz optiku osiromašenih i pojednostavljenih postavki.

Spoznajne pretenzije znanosti imaju svoje granice, a te granice nisu proizvoljne, nego su upisane u samu ljudsku narav, zatim u narav svijeta, upravo kao kontingentnoga i utoliko ne-nužnoga svijeta, te naposljetku u narav same ljudske spoznaje. Prema tome, polazište po kojem znanost kao takva ima spoznajne granice ne počiva na proizvoljnom, nego na spoznajnom argumentu naravi spoznaje (Matulić, 2006, 317). Ideja granice spoznaje podrazumijeva razgraničenje između ograničene i neograničene spoznaje, a to zatim nameće pitanje o razgraničenju između ljudske, tj. naravne ili ograničene spoznaje te neograničene ili Božanske spoznaje. Prema tome, granice znanstvene spoznaje izvode se iz spoznaje same naravi, bilo ljudske, svijeta ili spoznaje, čija inherentna neograničenost ne znači bez granica, nego znači neograničene mogućnosti spoznaje, pa sve do spoznaje same neograničenosti, tj. Boga. Stoga je na mjestu sud da spoznaja znanosti kao takve može sačinjavati samo jedan „nesavršeni”, a ne ujedno „savršeni” totalitet, jer konačno spoznajno savršenstvo nije dano u ograničenom, nego samo u neograničenom, tj. u Bogu (Matulić, 2006). Prema tome, cjelina znanstvenosti ili kumulativno prikupljene sve znanstvene spoznaje u jednu cjelinu opet ne sačinjavaju "čistu cjelinu”, nego samo "iskustvenu cjelinu”, tj. cjelinu koja je nastala kao rezultat različitih empirijskih — znanstvenih — opisa zbilje, a ne kao rezultat spoznaje „čiste cjeline”. No, iako znanost s punim pravom hita prema povećanju

3 De Bois Reymond je dao tu izjavu 1880. godine u govoru pred Berlinskom akademijom za znanost. U: URL: https://ipfs.io/ipfs/.../wiki/Ignoramus_et_ignorabimus.html (15.09.2018.) 
„cjeline” znanstvene spoznaje, ipak se može konstatirati da ta „čista cjelina spoznaje" ostaje neuhvatljiva, ali ne zbog toga što to netko proizvoljno hoće, nego zbog naravi spoznaje, naravi spoznajnoga subjekta i naravi spoznajnoga objekta. Tu činjenicu važno je istaknuti u kontekstu rasprave o scijentizmu, odnosno o ideološkim zloporabama znanosti, da bi se bilo svjesno činjenice da scijentizam označava radikalno suprotstavljanje jednomu metafizičkomu obliku spoznaje, koji se utemeljuje teološki, tj. na vjeri usidrenoj u transcendenciji. Naravno, ne bi trebalo zaboraviti ni drugu stranu, točnije fideizam, kao protureakciju na scijentizam, koji također zaslužuje osudu i odbacivanje.

Osim prethodno navedenoga, može se kazati da su ograničenja znanosti još i granice zablude (znanstveni um je onemogućen svojim vlastitim nedostatcima), ekonomske granice (znanstveni napredak postaje ovisan o kapitalu) te moralne granice, koje se uvijek pojavljuju kad se znanstveni napredak okreće protiv samoga čovjeka. Može se kazati da je znanost uvijek u suštini nešto nedovršeno: nedovršena ograničenja i nedovršena bezgraničnost — zbiljska utopija znanosti (Mittelstraß, 2001, 96).

»Na kraju, očevidnost ideologizacije znanosti danas se najjasnije pokazuje na raznim poljima primijenjene znanosti, tj. tehnike i tehnologije. Naime, svođenje znanosti na tehniku ima dalekosežne posljedice, prvo, za razumijevanje znanosti općenito, drugo, za razumijevanje znanosti kao ljudske djelatnosti i, treće, za razumijevanje određenog društvenog sektora koji je nezamisliv bez primjene određenih znanstvenih spoznaja« (Matulić, 2006, 96).

U tom je smislu indikativna Heideggerova misao: »Najgore smo, međutim, izloženi tehnici, ako na nju gledamo kao na nešto neutralno; jer ta nas predodžba, kojoj se danas osobito rado priklanjaju, čini potpunoma slijepima za bit tehnike« (Heidegger, 1996, 221).

Znanstvene tvrdnje i ideje utječu na sociokulturne vrijednosti, usmjeravaju društvenu akciju, utječu na stajališta o društvenoj jednakosti, na shvaćanje ljudske i fizičke prirode, na kulturne ideale o osobnoj slobodi i odgovornosti. Prema tome, koncepciju znanosti kao autonomne i vrijednosno neutralne potrage za istinom treba odbaciti. Usto, treba uzeti u obzir da, tvrdeći epistemički privilegirani status znanstvene spoznaje, ta koncepcija oslobađa znanstvenike od odgovornosti za posljedice njihovih istraživanja i oduzima javnosti pravo donošenja bilo kakve ocjene o društvenoj vrijednost, poželjnosti, isplativosti pojedinih znanstvenih projekata. Mnogi znanstvenici smatraju da se u znanosti, jer je objektivna, ne pojavljuju u spoznajama bitnija etička pitanja. Stajalištem da moralnost i etika ne igraju nikakvu ulogu u temeljnoj znanosti, jer ona otkriva samo objektivne istine, mnogi se znanstvenici opiru nadzoru njihova rada bez obzira na etičke posljedice. Primjerice, nobelovac Max Born rekao je da su »prirodne znanosti i tehnologija uništile, možda nepopravljivo, etičke temelje civilizacije « (Born, 1968, 273). Neprijeporno je da sve akutnija postaje potreba za uspostavljanjem zajedničkih vrijednosti i mjerila, kao i za promicanje etičkih načela i standarda za usmjeravanje znanstvenoga napretka i tehnološkoga razvoja. Znanost je danas postala previše moćna i važna da bi se ocjene o društvenoj vrijednosti 
pojedinih njezinih projekata mogle prepustiti samo znanstvenoj eliti i njezinim političkim i industrijskim saveznicima. Potreban je, dakle, dijalog između znanstvenika i raznih predstavnika ne-ekspertne javnosti.

\section{Dijalog između teologije i znanosti temeljen na transdisciplinarnom pristupu}

Opravdano je pitanje: Je li uopće moguć dijalog? Svaka osoba ima svoje predrasude, svoja uvjerenja, svoju podsvijest, koja bitno utječe na mentalitet i opće ponašanje pojedinaca. Kad dvoje ljudi pokušava komunicirati, neizbježno je sučeljavanje: stajalište protiv stajališta, podsvijest protiv podsvijesti. Budući da je taj sukob podsviješću, često dolazi do sukoba. Strogo gledajući, dijalog je vrlo teško voditi u odsutnosti odgovarajuće metodologije. Može se samo monologizirati. Dijalog ne znači kompromis da bi se potkopala nečija idejna zgrada.

Dijalog između teologije i znanosti treba biti ponajprije »razgovor čovjeka s čovjekom o bitnim interesima njega samoga (Oslić, 2007, 303). U kritičkom propitivanju teoloških i prirodoznanstvenih pitanja bitan je dijalog u smislu Platonove „nepisane dijalektike”, koja na temelju pitanja i odgovora traži nove putove promišljanja. Da bi se dijalog mogao ostvariti, potrebno je imati jednu širinu pogleda, koji je a priori protiv toga da se cijela stvarnost svodi samo na materiju. Dakle u svemu je tome uključen jedan dijalektički moment, koji u pozitivnom smislu mijenja sugovornike. Dijalog je to koji ulazi u još nepoznato područje i u kojem se susreću stalno i uvijek nanovo aktualizirano razumijevanje teologije stvaranja i nove spoznaje znanosti.

No, danas se unutar postmodernih tendencija pojavljuju razni pokreti koji predstavljaju određenu epistemičku dosljednost i zadobivaju povjerenje $\mathrm{u}$ znanstvenoj zajednici vezano uz povezivanje znanosti i religije. A jedan od takvih pokreta je transdisciplinarni pristup (Nicolescu, 2002; Cerovac, 2013; Poli, 2009, 135). Transdisciplinarnost je, slikovito rečeno, točka »susreta ljudi i uma« (UNESCO, 1998, IV) i predstavlja oblik integrativnoga istraživanja. Pojam transdisciplinarnost prvi je uveo 1970. godine filozof Jean Piaget (1896.-1980.), a izvorno je označavao stanje iznad interdisciplinarnosti, odnosno stanje u kojem ne postoje stabilne granice između disciplina (Nicolescu, 2002, 1). Može se reći da je transdisciplinarnost praktično jedini način pristupanja sve složenijim pitanjima, problemima i društvenim kontekstima znanosti, a riječ je o kombinaciji disciplinarnoga i nedisciplinarnoga, neformalnoga, nekodificiranoga prešutnoga znanja. Transdisciplinarnost se može shvatiti kao teoretski pokušaj, koji "nadmašuje discipline" te tako reagira protiv hiperspecijalizacije, procesa koji je doveo do dramatičnoga rasta fragmentacije znanja, a koji istodobno zadržava prednosti kreativnosti i individualne inicijative svojstvene određenomu području spoznaje i znanja (UNESCO, 1998, 3).

U razmatranju transdisciplinarnosti potrebno je uočiti njezin odnos prema multidisciplinarnosti i interdisciplinarnosti. Multidisciplinarnost se uglavnom 
shvaća kao oblik suradnje, koji pritom održava granice između pojedinih disciplina. Kod multidisciplinarnoga pristupa stručnjaci za pojedine discipline rade zajedno, zadržavajući pritom svoje disciplinarne pristupe i poglede. Posljedica je podjela rada u kojoj različiti disciplinarni okviri istražuju zasebne aspekte iste cjeline. Prema tome, multidisciplinarni pristup znači istraživanje nekoga određenoga fenomena, te da je ono napravljeno od strane nekoliko znanstvenika iz različitih disciplina, koji rade polazeći od svojih disciplina. Multidisciplinarnost stoga čuva ideju o disciplinarnoj autonomiji. Interdisciplinarni pristup posvećen je istraživanju u kojem znanstvenici, iz dvije ili više disciplina, rade zajedno u područjima koja se preklapaju ili u područjima koja se međusobno presijecaju, pa se interdisciplinarnost može shvatiti kao gradnja zajedničkoga modela za discipline koje su uključene. Interdisciplinarno istraživanje stoga zahtijeva zajedničku formulaciju problema i, barem donekle, zajednički metodološki okvir za istraživanje različitih tema ili aspekata istraživanja problema.

Transdisciplinarnost povećava vjerojatnost dijaloga i obostrano razumijevanje, kao i razmjenu znanja i informacija. Taj pristup može okupiti sve koji misle različito, odnosno zastupaju različite svjetonazore i vjeronazore te može riješiti probleme, koji se ne mogu riješiti izoliranim naporima. To je ponajprije jedan integrirajući, iako ne i holistički pristup, koji rješava izolaciju na višoj metodološkoj ravnini, no pritom ne pokušava konstruirati čvrstu obrazlagajuću matricu. Drugim riječima, transdisciplinarnost prelazi granice između oblika znanja uzimajući u obzir raznovrsnost, složenost, neizvjesnost i vrijednosti određenoga pitanja. Takav pristup ima, dakle, posredničku ulogu, koja za »okruglim stolom « ${ }^{4}$ (Oslić, 2007, 302) od sugovornika traži ono što ljude povezuje na razini općeljudskoga. Treba izgrađivati svijet kulture koja se nadahnjuje tradicijom, ali koja odgovorno misli i na budućnost budućih naraštaja. To je izgrađivanje jednoga »bazena općeljudskoga ${ }^{5}{ }^{5}$ u kojem se susreću humanističke i prirodne znanosti. Dijalog ne znači neki kompromis kojim se potkopava nečija idejna zgrada. Susret ljudi u »bazenu općeljudskoga « znači ne samo prihvaćanje partnerova svijeta kao još uvijek ljudski mogućega, nego i ugrađivanje kršćanske misli u aktualnost današnjega svijeta kao autentične ljudske mogućnosti, a ne kao nekoga anakronizma. Transdisciplinarnost ponajprije je jedna integrirajuća zamisao utemeljena na slobodi razmišljanja među disciplinarnim granicama. Riječ je, dakle, o istraživanju koje se u bitnom obujmu kreće izvan disciplinarnih ograničenja i koje svoje probleme definira neovisno o disciplinama te ih zatim rješava idući izvan tih ograničenja (Mittelstraß, 2016). To je put do plodnoga dijaloga između teologije i znanosti. Za razliku od disciplinarnoga načina razmišljanja, koji teži konsenzusu, transdisciplinarno se istraživanje, kako kaže Thierry Ramadier $(2003,434)$ zasniva na »kontroliranom sukobu što ga stvaraju paradoksi «.

4 Termin Vjekoslava Bajsića.

5 »Budući da ljudi jedni drugima priopćuju svoje spoznaje, to se istina može tražiti u 'bazenu' općeg govora koji se tvori neprestanim dijalogom između ljudi. Ako se, dakle, želi znati istina o nečemu, valja pitati što se o tom općenito kaže, jer 'kolikostruko se kaže tolikostruko biti znači' (Aristotel, Met., V, 7, 1017a23s;)“"(Tadić, 2015, 48) 
Transdisciplinarnost nije još jedna disciplina, iako na prvi pogled i uz nedostatak odgovarajućega opisa to tako izgleda. Istodobno, trasdisciplinarnost nije pristup koji može riješiti sve nejasnosti i sve poteškoće s kojima se znanstvenici susreću u kontekstu današnje hiperspecijalizacije i fragmentacije znanosti, a što sprječava pristup širemu i povezanomu znanju. Ona podrazumijeva znanje koje treba prodrijeti, i biti integrirano, u bilo koje područje. Razmišljati transdisciplinarno znači pretpostaviti nekoliko razina stvarnosti, što podrazumijeva drugačiji konceptualni okvir u ulasku u unutarnjost jastva bića. Kad je u pitanju prirodni, fizički svijet, može se govoriti o najmanje tri razine stvarnosti: o mikrofizikalnoj i makrofizikalnoj, te o cyber prostorno-vremenskoj stvarnosti (Cerovac, 2013, 23; Nicolescu, 2010, 19), a u duhovnom prostoru kršćanske misli može se govoriti o dvije razine stvarnosti: božanskoj i ljudskoj.

Transdisciplinarnost se temelji na tri aksioma (postulata), koji usmjeruju njezinu metodu, a postavio ih je 2002. kvantni fizičar Basarab Nicolescu (Nicolescu, 2002, 15-38):

1. Ontološki aksiom (razine Stvarnosti): ${ }^{6}$ u prirodi i u ljudskom poznavanju prirode, postoje različite razine Stvarnosti (engl. Reality) i, prema tome, različite razine opažanja.

2. Logički aksiom: prijelaz od jedne do druge razine Stvarnosti osiguran je logikom uključene sredine.

3. Aksiom složenosti: struktura ukupnih razina Stvarnosti, ili opažanja, složena je struktura: svaka razina je ono što jest, jer sve razine postoje istodobno.

Navedena tri aksioma daju preciznu i strogu definiciju transdisciplinarnosti. Prema Nicolescuovu tumačenju, prva dva aksioma potvrđena su u 20. stoljeću eksperimentalno pomoću kvantne fizike, a treći aksiom, osim u kvantnoj fizici, ima potvrdu i u drugim područjima prirodnih znanosti. Aksiomi nisu dokazivi, jer nisu teoremi, i predstavljaju temeljnu istinu, pretpostavka su na kojoj se gradi teorija, a svoje korijene imaju u eksperimentalnim podatcima i teorijskim pristupima znanosti. Navedena tri aksioma stupovi su transdisciplinarnosti i određuju metodu transdisciplinarnoga istraživanja (Nicolescu, 2002, 45). Ključni koncept transdisciplinarnoga pristupa prirodi i znanju je koncept razine Stvarnosti.

Priznavanje postojanja različitih razina Stvarnosti upravljanih različitim vrstama logike svojstveno je transdisciplinarnomu stajalištu. Svaki pokušaj reduciranja Stvarnosti na samo jednu razinu upravljanu jednom logikom ne leži u okviru transdisciplinarnosti. [...] (Nicolescu, 2002, 148) Dvije su različite razine Stvarnosti, različite ako prelaskom s jedne na drugu postoji prekid u zakonima te prekid u temeljnom konceptu, primjerice, poput uzročnosti (Nicolescu, 2002, 21). ${ }^{7}$

6 Riječ Stvarnost je pisana s velikim slovom kao doslovni prijevod termina Reality iz knjige Manifesto of Transdisciplinarity Basarabe Nicolescua. »Pojmom Reality (veliko R) označava se ponajprije sve ono što odolijeva našim iskustvima, prezentacijama, opisima, slikama ili matematičkim formulacijama« (Nicolescu, 2002, 20). Citati na hrvatskom jeziku iz engleskih izvornika prijevod su autora ovoga članka.

7 Ta problematika detaljno je opisana u: Cerovac, 2013. 
Ono što razlikuje transdisciplinarni pristup dijalogu između znanosti i religije u odnosu na interdisciplinarni pristup jest da interdisciplinarna metodologija ima za cilj sažeti glavna pitanja pojedinih disciplina u dijalogu u obliku nove akademske discipline, a transdisciplinarnost, koja nije nova disciplina, ili neka superdisciplina sama po sebi, pokušava postaviti dijalog izvan disciplinarnih granica međusobno povezanih disciplina. Stoga, kad se transdisciplinarnost koristi kao most za stvaranje dijaloga između znanosti i teologije, pojavljuje se sukob između dvaju područja znanja u njihovu statusu kao akademskih disciplina. Naglasak je na pojavljivanju novih rezultata i veza između disciplina njihovim otvaranjem prema onomu što im je zajedničko i onomu što leži izvan njihovih disciplinarnih granica. Transdisciplinarni pristup vidi teologiju kao partnera u dijalogu sa znanošću. Prema njezinim zagovornicima, transdisciplinarnost nije ni religijska ni nereligijska, nego je transreligijska.

Dakle, transdisciplinarnost je na neki način „dijaloška majeutika”, koja je temeljno načelo ljudske umnosti. Naime, dijaloška majeutika postaje, kako kaže važni hrvatski teolog i filozof Vjekoslav Bajsić (1924.-1994.), temeljno načelo naše umnosti, jer se on proteže na sve one koji nastoje međusobno komunicirati postavljajući sebi za cilj pronalaženje i osvjetljenje istine. Dijaloška majeutika djeluje uvijek na obje strane. Bajsić smatra da nas razum u bitnim stvarima ne vara, osobito u stvarima koje podliježu općemu interesu ljudi, kao što je primjerice smisao života, odnosno ono što je na neki način zajedničko svim ljudima (Oslić, 2007, 303).

Bajsićev pristup je zapravo transdisciplinarni pristup, iako ga on naziva interdisciplinarnim, jer ukazuje da prirodne ili humanističke znanosti ne mogu više ostati zatvorene u vlastite svjetove, nego je potrebno progovoriti o međusobnoj upućenosti jednih na druge. Upravo ta međusobna upućenost omogućuje ozračje u kojem se stvaraju preduvjeti za preuzimanje odgovornosti, kako u našoj sadašnjosti, tako i u budućnosti.

»Prema Bajsićevu mišljenju, 'dijalog' u sebi bitno implicira i jedan 'dijalektički moment', koji u pozitivnom smislu mijenja sugovornike u smislu prihvaćanja jednog zajedničkog konsensusa (dogovora), koji se u etičkom smislu može nazvati principom 'transsubjektivnosti'. Iz Bajsićevih tekstova može se jasno isčitati jedna 'metodika dijaloga' kojoj je svrha pristupiti onom Drugom i drukčijem«(Oslić, 2007, 302).

Da bi se dijalog mogao ostvarivati, potrebno je imati jednu širinu pogleda, koji je a priori protiv toga da se cijela stvarnost svede samo na materiju.

„Zahtjevi” za transdisciplinarnošću ne umanjuju važnost posebnih znanosti i znanstvenih disciplina u spoznavanju njihova predmeta pojava, ali su bitni kao epistemičko-metodološki pokušaji kritičkoga razmatranja njihovih spoznajnih dometa. Metoda dijaloške majeutike omogućuje Bajsiću pristup k bazenu općeljudskoga, u kojem se zrcale ne samo postignuća humanističkih, nego i ona prirodnih znanosti. Na tragu tih promišljanja je transdisciplinarni pristup.

Postavljenomu zadatku ne mogu odgovoriti mnogi dosadašnji pravci filozofijskoga pozitivizma, pragmatizma i empirizma sa svojim neo- dodatcima. Transdisciplinarni pristup stvara ozračje za jedno novo tumačenje stvarnosti i vodi 
mirnijem dijalogu između znanosti, epistemologije, povijesti znanosti, filozofije, etike i teologije.

Veliki izazov i zahtjev trećega tisućljeća neće postati utopija, ako će se protagonisti svih disciplina i kultura konstruktivno sučeljavati, te vjerno surađivati na uzajamnom i skladnom povezivanju. Spoznaji i kulturama koje traže svoj smisao i sudbinu u mnogim smjerovima, često ne nalazeći ih, kršćanska Objava, ojačana višetisućnim poređenjem i dijalogom s kulturama, društvima i znanjima svih vremena i mjestima, nudi nadu u svijetlu Mudrosti i snage Logosa (Gismondi, 2002).

\section{Zaključak}

Na temelju istaknutoga u ovom članku možemo zaključiti da transdisciplinarnost povećava mogućnost i uspješnost dijaloga i uzajamnoga razumijevanja, kao i razmjenu znanja i informacija. Transdisciplinarni pristup prelazi granice između „oblika” znanja, uzimajući u obzir raznolikost, kompleksnost, nesigurnost i vrijednosna pitanja. Stoga, čini se da bi transdisciplinarni pristup mogao okupiti velik broj onih koji misle različito, odnosno zastupaju različite svjetonazore i vjeronazore, te bi mogao riješiti neke od problema koji se ne mogu rješavati izoliranim naporima. Nadalje transdisciplinarnost zasigurno širi perspektive jer se s ciljem poboljšanja međusobnoga razumijevanja koristi konceptima brojnih disciplina. Tako se transdisciplinarnost može smatrati intelektualnim prostorom u kojem se priroda mnogostrukih međusobno izoliranih pitanja može istraživati i otkrivati. Riječ je o generaliziranom prekoračenju koje otvara neograničen prostor za slobodu, razumijevanje, toleranciju i ljubav (Nicolescu, 2002, 74).

»Življena transdisciplinarnost može dovesti ne samo do promjene načina kako razmišljamo, nego i do promjene ponašanja « (Nicolescu, 2002, 142). Rasprava o transdisciplinarnosti još je uvijek svježa i ideja transdisciplinarnoga istraživanja još je u razvoju. No, činjenica je da:

Velike novine vezane uz problematiku razvoja naroda danas u mnogim slučajevima nameću potrebu za novim rješenjima. Njih treba tražiti kako u poštovanju zakona na svim razinama tako i u svijetlu cjelovitog pogleda na čovjeka, koji odražava različite vidove ljudske osobe, a riječ je o pogledu pročišćenom ljubavlju. Tada će izaći na vidjelo određene konvergencije i konkretne mogućnosti rješenja, a da pritom ne bude potrebno odreći se nijedne temeljne sastavnice ljudskog života (CV 32).

U tom smislu, transdisciplinarni pristup pokazuje se kao moguće rješenje. Naime, zahtjevi za transdisciplinarnošću ne poništavaju važnost posebnih znanosti i znanstvenih disciplina u spoznaji njihova predmeta, ali su bitni kao epistemološki metodološki pokušaji kritičkoga razmatranja njihovih spoznajnih dometa. Umjesto superspecijalizacije znanja i „feudalizacije” disciplina, transdisciplinarnost nastoji spojiti »područja ljubomorno čuvana jednih od drugih tradicionalnom (modernom) organizacijom znanja« (Lyotard, 1984, 52).

Dodatno, valja istaknuti kako znanost nije, niti može biti, razlog za nevjerovanje, jer to nije znanstveno pitanje. Štoviše, znanost je u vezi s vjerom potpuno neutralna. U tom smislu, treba podsjetiti na dvije misli Vjekoslava Bajsića, koji je 
vrlo mnogo zadužio hrvatsku filozofsku i teološku misao i koji je u svoje doba bio među rijetkima, koji su se upuštali u teološko razmatranje tzv. graničnih pitanja znanosti i religije.

Možda je u svemu najteže što bi se tek morao pripraviti teren za takvu 'dijalošku filozofiju' koja — još jednom budi rečeno — nije ni kompromis ni sinkretizam, nego traženje 'prirodnog' sustava mišljenja u najboljem smislu riječi baš na temelju sokratske pretpostavke da je ljudski intelekt sposoban da spozna istinu i da se ona na naravnom planu samo tu može naći (Oslić, 2015, 32).

»Mislim da ne bi trebalo, uza svu važnost znanosti za čovjeka, naglašavati da znanost nipošto ne iscrpljuje sve realno. Ima vrlo važnih stvari za pojedinca koje po definiciji stoje izvan domašaja ili potpunog domašaja znanosti«(Bajsić, 1986, 356).

Na koncu, kršćanstvo obuhvaća sve aspekte ljudskoga postojanja, bivajući transdisciplinarno, jer traži konačno jedinstvo znanja i ljudskoga postojanja. Ali, isto tako, »ljudsko je znanje kao cjelina transdisciplinarno, a transdisciplinarna je također i inteligencija kao jedan od bitnih uvjeta postojanja«(Pop, 2009, 58).

\section{Literatura:}

Bajsić Vjekoslav (1985). Izazov prirodoznanstvene civilizacije. Bogoslovska smotra, 55(34), 346-359.

Barth, Karl (2003). God Here and Now. London: Routledge.

Benedikt XVI. (2008). Vjera i budućnost. Zagreb: Kršćanska sadašnjost.

Born, Max (1968). Erinnerungen und Gedanken eines Physikers. U: Der Luxus des Gewissens: Erlebnisse und Einsichten im Atomzeitalter (str. 273). München: Nymphenburger Verlagshandlung.

Cerovac, Krešimir (2013). Transdisciplinarni pristup učenju i istraživanju na sveučilištu. Metodički ogledi, 20(1), 15-31.

CV. Caritas in veritate. Benedikt XVI., Caritas in veritate: Ljubav u istini. Zagreb: Kršćanska sadašnjost, 2009.

EG. Evangelii gaudium. U: Franjo, Evangelii gaudium: Radost evanđelja: Apostolska pobudnica biskupima, prezbiterima i đakonima, posvećenim osobama i svim vjernicima laicima o naviještanju evanđelja u današnjem svijetu. Zagreb: Kršćanska sadašnjost, 2013.

FR. Fides et ratio. Ivan Pavao II., Fides et ratio: Vjera i razum: Enciklika svim biskupima Katoličke crkve o odnosu vjere i razuma. Zagreb: Kršćanska sadašnjost, 2004.

Gismondi, Gualberto (2002). Culture. U: INTERS: Interdisciplinary Encyclopedia of Religion and Science. URL: http://www.inters.org/ (10.06.2019.)

GS. Gaudium et spes. Drugi vatikanski koncil, Pastoralna konstitucija Gaudium et spes o Crkvi u suvremenom svijetu. U: Josip Turčinović (ur.), II vatikanski koncil: Dokumenti: Latinski i hrvatski (str. 620-768). Zagreb: Kršćanska sadašnjost, 1993.

Heidegger, Martin (1996). Pitanje o tehnici. Naprijed: Zagreb.

Ivan Pavao II. (1988). Letter of His Holiness John Paul II to Reverend George V. Coyne, S.J. Director of the Vatican Observatory. URL: https://w2.vatican.va/content/john-paul-ii/ en/letters/1988/documents/hf_jp-ii_let_19880601_padre-coyne.html (10.06.2019.)

Kusić, Ante (1997). Krist: Počelo i svrha svega: Kozmogeneza — antropogeneza — sjedinjenje u "točki omega". Đakovo: Forum bogoslova. 
Lyotard, Jean-Francois (1984). The Postmodern Condition: A Report on Knowledge. Minneapolis: University of Minnesota.

Matulić, Tonči (2006). Mogućnosti i granice suvremene znanosti: Epistemološke i etičke analize iz teologijske perspektive. Bogoslovska smotra, 72(2), 285-333.

Mittelstraß, Jürgen (2001). Science as Utopia. U: Science and the Future of Mankind (str. 96). Vatican City: Pontifical Academy of Sciences.

Monod, Jacques (1971). Chance and Necessity: An Essay on the Natural Philosophy of Modern Biology. New York: Alfred A. Knopf.

Mościcki, Paweł (2015). Engagement and Autonomy of Theatre. Polish Theatre Journal, $1,1-15$.

Nicolescu, Basarab (2002). Manifesto of Transdisciplinarity. New York: State University of New York.

Nicolescu, Basarab (2010). Methodology of Transdisciplinarity: Levels of Reality, Logic of the Included Middle and Complexity. Transdisciplinary Journal of Engineering \& Science, 1(1), 19-38.

Oslić, Josip (2007). Religija i znanost u djelu Vjekoslava Bajsića. Filozofska istraživanja, 27(2), 295-305.

Oslić, Josip (2015). Ususret Vjekoslavu Bajsiću. Bogoslovska smotra, 85(1), 25-40.

Poli, Roberto (2009). Two Theories of Levels of Reality: In Dialogue with Basarab Nicolescu. Transdisciplinarity in Science and Religion, 6, 135-153.

Pop, Ioan G.; Vereş, Otniel L. (2009). The Transdisciplinarity and Christian Thought. Transdisciplinarity in Science and Religion, 6, 57-68.

RH. Redemptor hominis. Ivan Pavao II., Redemptor hominis: Otkupitelj čovjeka. Zagreb: Kršćanska sadašnjost, 1997.

Tadić, Stipe (2015), Vjekoslav Bajsić u dijalogu, Bogoslovska smotra, 85(1, 41-56)

Trigg, Roger (2015). Beyond Matter: Why Science Needs Metaphysics. West Conshohocken: Templeton Press.

UNESCO (1998). Transdisciplinarity: Stimulating Sinergies, Integrating Knowledge, Division of Philosophy and Ethics. Paris: UNESCO.

Whitehead, Alfred North (1997). Science and the Modern World. New York: The Free Press.

Wilson, Edward O. (1975). Sociobiology: The New Synthesis. Cambridge MA: Harvard University.

Wilson, Edward O. (1988). On Human Nature. Cambridge MA: Harvard University. 
A Transdisciplinary Approach to the Consideration of the Relationship between Natural Science and Theology

\section{Krešimir Cerovac*}

\section{Summary}

There are many reasons why a partnership dialogue between theology (religion) and the natural sciences is needed. However, first and foremost this must be a conversation between one human being and another regarding the most important of human interests. The most effective way to approach complex issues and problems in the dialogue between theology and science is the transdisciplinary approach.

Transdisciplinarity can solve problems which cannot be resolved by separate attempts. This approach can connect different modes of thought, that is, thought beginning with different points of view on the material world or religion. The transdisciplinary approach takes on the role of mediator, which demands at the "round table" that which unites human beings on a universal human level. This is a new, challenging and demanding approach which requires researchers to leave their own field of interest and strive to learn about other fields.

The transdisciplinary approach, as "critical rationality" and a new way of thinking, opposed to classical and reductive rationalism, emphasizing objectivity, is based on controlled conflict-induced paradoxes. Transdisciplinarity creates a new quality which is not an arithmetic sum of individual disciplines - and enables articulation, i.e. a link between two, at first glance, controversial disciplinary modes of thought.

Key words: dialogue, dialogical maieutics, epistemological limits, interdisciplinarity, multidisciplinarity, religion, science, scientism, theology, transdisciplinarity, transdisciplinary axioms

* Krešimir Cerovac, M.Sc., mag. ing. el. techn. Address: Našička 2, 10000 Zagreb, Croatia, E-mail: kresimir.cerovac@xnet.hr 